\title{
Sąd polubowny w Grazu - ksztaltowanie się organizacyjnej koncepcji rozstrzygnięcia sporu granicznego i podteksty tego procesu
}

\section{STAN BADAŃ}

Pierwsze publikacje poświęcone galicyjsko-(austriacko-)węgierskiemu sporowi o Morskie Oko pojawiają się nie tyle jako reakcja na nabycie (1879 r.) przez Prusaka, ks. Christiana Hohenlohe, dóbr jaworzyńskich, graniczących w Tatrach z Galicją, ile jako przeciwdziałanie realizacji przez nowego właściciela na spornym od wieków obszarze pretensji do tatrzańskich gruntów. Ustalenie przynależności politycznej (państwowej) obszaru okalającego to jezioro należy traktować jako niezbędny krok do rozstrzygnięcia równolegle występującego, podstawowego sporu o własność prywatną na tym obszarze. Przewagę ilościową wśród opracowań mają te dotyczące sporu publicznoprawnego, w większości o walorze praktycznym, gdyż służyć miały gromadzeniu informacji potwierdzających polskość spornego terytorium lub promowaniu stanowiska obrońców polskich praw do Morskiego Oka ${ }^{1}$. Natomiast konflikt prusko-polski między właścicielem dóbr jaworzyńskich, ks. Hohenlohe, a właścicielem od 1889 r. państwa zakopiańskiego, hrabią Zamoyskim, budził mniejsze zainteresowanie badaczy ${ }^{2}$. Istotne jest też, że współczesne opracowania

\footnotetext{
${ }^{1}$ Zestawienie publikacji poświęconych sporowi zob. Z. Nowak, Władysław Zamoyski a spór o Morskie Oko w latach 1890-1909, „Pamiętnik Biblioteki Kórnickiej” 1986, z. 21, s. 43-136. Aktualizacji zestawienia dokonał J.M. Roszkowski, Walka o Morskie Oko w Tatrach 1811-1909, Kórnik 2018, s. 205 i n.

${ }^{2}$ Rozróżnienie opracowań poświęconych pierwszemu lub drugiemu sporowi bywa niekiedy trudne, skoro niektórzy z badaczy te dwa konflikty przedstawiają łącznie, jako jeden. Por. uwagi w tej kwestii: J. Matuszewski, Ile procesów o Morskie Oko? [w:] Origines, fontes et narrationes -
} 
mają głównie charakter jubileuszowy (np. stulecie procesu z 1902 r.), a w takich niełatwo zamieszczać uwagi podważające dotychczasowy dorobek, zwłaszcza ze względu na jego silnie patriotyczny wydźwię $k^{3}$.

Wypowiedzi dotyczące obu sporów (prawa publicznego i prawa prywatnego) cechuje to, co można by uznać za mankament wszystkich studiów poświęconych tej tematyce: założenie, że dotychczasowe ustalenia, zwłaszcza te $\mathrm{z}$ lat toczącego się sporu i związane z procesem w Grazu, nie wymagają jakiejkolwiek krytyki ${ }^{4}$.

Sformułowany wyżej zarzut należy odnieść także do traktowania przywoływanej w tych pracach podstawy źródłowej ${ }^{5}$. Materiały te, zarówno archiwalne, jak i wciąż w czasie procesu aktualne (np. kartografia), były gromadzone i analizowane przez badaczy w trakcie przygotowania do procesu, przede wszystkim w celu dostarczenia dowodów potwierdzających pełnię polskich praw do Morskiego Oka. Ponadto punktem odniesienia podstawy źródłowej, jak i oceny formułowanych wypowiedzi powinien być wydany 13 września 1902 r. wyrok trybunału arbitrażowego w Grazu. Wyrok ten jest jednak dotknięty skazą non leguntur. Powszechnie bowiem bezrefleksyjnie przedstawiany jest jako korzystne dla Galicji (Austrii) rozstrzygnięcie sporu. A sukces ten Galicja miała zawdzięczać - zdaniem ówczesnych, a także współczesnej nam literatury - znakomicie przygotowanej i przedstawionej argumentacji prof. Oswalda Balzera, obrońcy polskich (austriackich) praw, przede wszystkim w toku jego czterodniowych wystąpień przed sądem rozjemczym. Można jednak odnieść wrażenie, że fakt przyznania Galicji większości spornego obszaru w procesie o terytorium przy Morskim Oku przesłania zdolność do obiektywnego traktowania przedmiotu badań. Zdajemy sobie sprawę, że w chwili wydania orzeczenia wyrok ustalający granice między Austrią a Węgrami przy Morskim Oku miał szczególną emocjonalnie, społeczną i polityczną wartość dla rozdzielonej między trzy państwa rozbiorowe społeczności polskiej, zwłaszcza wobec równoległych germanizacyjnych i rusyfikacyjnych wydarzeń w pozostałych zaborach. Uważamy jednak, że dziś brak dostatecznych powodów

pośród kręgów poznania historycznego. Prace ofiarowane Profesorowi Marcelemu Antoniewiczowi w 65. rocznicę urodzin, Częstochowa 2018, s. 805-813.

${ }^{3}$ Por. ostatnie zakwestionowanie walorów orzeczenia z Grazu ze wskazaniem, że spór o granice w Tatrach zakończył się, wbrew powszechnemu przekonaniu, realnym sukcesem Węgrów: J. Matuszewski, Przypadek sq̨du polubownego z 1902 roku. Międzynarodowy trybunat w Grazupowołanie, struktura, jurysdykcja, funkcjonowanie i orzeczenie (teoria spiskowa) [w:] A. Moniuszko, M. Wąsowicz, A. Zakrzewski (red.), O przemianach kultury prawnej, Warszawa 2021.

${ }^{4}$ Tego rodzaju podejście historiografii do przedmiotu badań dostrzeżono już i krytykowano, np. zwracając „uwagę na konwencje, do których przyzwyczaja się czytelnika od czasów szkolnych [a które są] tak skostniałe i ugruntowane w tradycji, że nikt nie poświęca im chwili namysłu". A. Leszczyński, Ludowa historia Polski. Historia wyzysku i oporu. Mitologia panowania, Warszawa 2020, s. 5.

${ }^{5}$ Można odnieść wrażenie, że większość piszących ogranicza się, zapewne bez autopsji, do przywołania źródeł, które wykorzystali poprzednicy. 
do subiektywizowania badań tymi właśnie okolicznościami. Aspekt patriotyczny tego procesu nie powinien usprawiedliwiać utraty zdolności do obiektywnej analizy i oceny ilustrującego przebieg wydarzeń materiału źródłowego. Tym bardziej gdy uświadomimy sobie, że w uzasadnieniu wyroku trybunał jednoznacznie stwierdził, że żadna (!) ze stron nie potrafiła wykazać swoich praw do żądanej linii granicznej. Dotyczy to zatem także wywodów Oswalda Balzera.

Współczesna nam nauka dostrzegła już wiele amplifikacji w licznych wypowiedziach czasów procesu i lat Polski międzywojennej. Zauważono też bezzasadne pomijanie kapitalnej roli Władysława Zamoyskiego w staraniach o zachowanie w granicach Galicji całej okolicy Morskiego Oka ${ }^{6}$. Dziś już nikt poważny nie przemilcza roli ostatniego pana na Kórniku, ale wciąż uznaje się za obiektywną podstawę do oceny praw pozostających w sporze stron materiały przedstawione $\mathrm{w}$ opracowaniu, przygotowanym w cztery lata po zakończeniu sporu, przez austriackiego obrońcę (prof. Balzera), a więc przedstawiciela jednej strony.

W prezentowanym studium podjęto kwestię - jak się okazuje, dość skomplikowaną - zaprojektowania i uchwalenia decyzji „o ustanowieniu granicy pomiędzy Galicyą a Węgrami przy tak zwanem »Morskiem Oku« w górach Tatrzańskich”. Pozostawiono natomiast na uboczu przebieg procesu, ,naocznię” (wizję lokalną), wyrok i jego społeczne przyjęcie.

\section{CHARAKTER SPORU}

Spór o Morskie Oko toczył się między Królestwem Węgier a Rzeczpospolitą od XVI w. jako międzypaństwowy spór graniczny, którego intensywność w praktyce zależała od zaangażowania granicznych magnatów: po stronie węgierskiej - Palocsayów, a po stronie polskiej - uczestniczących w nim na różnym poziomie aktywności starostów nowotarskich. O charakterze problemu granicznego decydowało to, że strefa graniczna przebiegała w wysokogórskim, trudno dostępnym obszarze. Dodatkową komplikację w stosunkach granicznych między starostwem nowotarskim a komitatem spiskim stanowiło posiadanie przez Królestwo Polskie starostwa spiskiego, dzierżonego od czasów Władysława Jagiełły prawem ustanowionego przez Zygmunta Luksemburskiego w 1412 r. zastawu, obejmującego oprócz terytorium ,polskiego Spisza” rozczłonkowany obszar, na który składało się sześć enklaw terytorialnych po węgierskiej stronie Tatr? ${ }^{7}$. Musiało to utrudniać wytyczenie, czy

${ }^{6}$ S. Sierpowski (red.), Władystaw Zamoyski 1858-1924, Kórnik - Zakopane 2003.

7 J. Kurtyka, Początki starostwa spiskiego i pierwsi starostowie. Z dziejów polityki Władysława Jagietly wobec Zakonu Krzyżackiego i Zygmunta Luksemburskiego w latach 1411-1430, „Studia z Dziejów Państwa i Prawa Polskiego" 2006, t. IX, cz. 1, s. 153-179; A. Divêky, Dzieje przyłaczenia miast spiskich do Wegier w r. 1770-ym, „Przegląd Historyczny” 1921-22, t. 23, nr 1, s. 17-60. 
tylko ustalenie w drodze praktyki, granicy linearnej między dwoma państwami, a sporne terytorium przy Morskim Oku przechodziło z rąk do rąk. W tej sytuacji spór między Polską a Węgrami można było rozstrzygnąć wyłącznie w drodze ugody między granicznymi państwami. Próby zawarcia takiego porozumienia były podejmowane, lecz za czasów Rzeczypospolitej nie udało się konfliktu rozstrzygnąć, być może i z tego powodu, że w okolicach Morskiego Oka sprawa dotyczyła terytorium bez szczególnej wartości materialnej (aspektów turystycznych nie dostrzegano), a także o niestabilnych elementach topograficznych.

Konflikt graniczny nasiliły austriackie akty zaboru ziem Królestwa Polskiego, zapoczątkowane już w 1768 r. utworzeniem przez Austrię na polskim terytorium kordonu sanitarnego i zajęciem trzymanych dotąd przez Polskę w zastawie miast spiskich. Już wtedy można dostrzec nowy, austriacko-węgierski spór o to, czy na granicy obszaru kwarantanny należy ustawić znaki austriackie - dwugłowego orła czy herb Węgier ${ }^{8}$. Roszczenie węgierskie zostało odrzucone, niebawem jednak Maria Teresa włączyła zrabowany obszar wraz ze Spiszem do Węgier. Po trzech latach zmieniła decyzję i już po I rozbiorze uznała to polskie terytorium za część Austrii ${ }^{9}$. Z powodu rozbiorowej grabieży spór o granice w Tatrach między komitatem spiskim a Galicją stał się sporem o granice wewnętrzne monarchii, gdyż o przynależności tego terytorium mógł skutecznie decydować władca monarchii Habsburgów. Jednak po upływie stu lat od I rozbioru wciąż nierozstrzygnięty spór o przebieg granicy, w wyniku utworzenia w 1867 r. monarchii dualistycznej, przekształcił się ponownie w międzynarodowy konflikt ${ }^{10}$. W Austro-Węgrzech zabrakło organu do rozwiązania kontrowersji, nie ustanowiono żadnej władzy kompetentnej do rozstrzygania sporów granicznych między dwoma państwami stanowiącymi dziedzictwo Habsburgów, określanymi niekiedy mianem Przedlitawii (korona austriacka) i Zalitawii (korona węgierska) ${ }^{11}$.

${ }^{8}$ A. Divêky, Dzieje przyłączenia..., s. 23.

${ }^{9}$ Ibidem, s. 39.

${ }_{10}$ J. Matuszewski, Postępowanie sądowe, administracyjne czy polubowne? Spór jeden a procedur wiele [w:] W. Chróścielewski, Z. Kmieciak (red.), Idea kodyfikacji w nauce prawa administracyjnego procesowego, Warszawa 2018, s. 225-233. Uczestnikami sporu politycznego o granice stały się w 1867 r. dwa odrębne państwa: Austria i Węgry. Rząd Austrii, reprezentując na forum międzynarodowym interesy austriackie, równocześnie reprezentował interesy krajowe Galicji, czyli ostatecznie interesy polskie.

${ }^{11}$ „Brak zupełnie trybunału lub władzy, powołanej do orzecznictwa w sprawach granicznych »międzylitawskich«”. Zob. „Czas” nr 6 z 9.01.1896 r. Franciszek Józef był głową państwa austriackiego (cesarzem), a równocześnie, ale niezależnie, głową królestwa węgierskiego (królem). W obu państwach miał różne kompetencje, ale jako król sprawował władzę królewską tylko na Węgrzech, a jako cesarz tylko na obszarze państwa austriackiego. Inaczej uważa Z. Nowak, bez uzasadnienia wskazując: „nie było natomiast władzy, poza cesarzem, kompetentnej do rozsądzania takich sporów między Przedlitawią a Zalitawią". Z. Nowak, Władysław Zamoyski a spór..., s. 87. Takie stanowisko zajmują też inni badacze - J.M. Roszkowski stwierdza, też bez uzasadnienia, że „w państwie 
W takiej sytuacji politycznej jedynym rozwiązaniem, bo a limine odrzucamy możliwość wykorzystania przez spierające się Austrię i Węgry instrumentów militarnych ${ }^{12}$, jest ugoda. Może ona polegać albo na ostatecznym porozumieniu stron rozstrzygającym meritum sporu, albo na ustaleniu specjalnego postępowania, które ma doprowadzić do rozwiązania konfliktu. Pierwsza ze wskazanych możliwości była w tym przypadku realna i mogłaby ostatecznie zakończyć waśń graniczną. $\mathrm{Na}$ przeszkodzie stanęły jednak racje polityczne dualistycznej monarchii. W zakresie stosunków publicznoprawnych w latach 90. doszło już między rządem austriackim i węgierskim do poufnego porozumienia w tej sprawie, ale ugody międzynarodowej nie zawarto, gdyż rządy te nie chciały brać na siebie politycznej odpowiedzialności za konieczne w tej sytuacji wzajemne ustępstwa ${ }^{13}$. Dlatego doszło do porozumienia międzyrządowego w celu zastosowania odpowiedniego wybiegu. Uznano - jak mało roztropnie wyznał Tchorznickiemu premier austriacki Kazimierz Badeni - że ,jednak rządy nie mogą same takiej ugody zawrzeć, bo by tu Polacy narzekali na rząd, a Węgrzy zarzucali swemu rządowi, że darował część węgierskiej ojczyzny i że dlatego oba rządy pragną, by podział terytorium spornego uskutecznił sąd polubowny, który jest niezawisły i jako oparty na powadze sędziowskiej nie będzie wystawiony na tak liczne ataki" ${ }^{14}$. To znaczące, że ta wypowiedź premiera Austrii, zawierająca już wskazanie pożądanej decyzji, adresowana była do osoby, której Badeni proponował objęcie funkcji arbitra w mającym być powołanym trybunale rozjemczym.

Dodatkowym czynnikiem stymulującym działania władz obu monarchii było nasilenie na obszarze granicznym konfliktu, choć w tym przypadku w grę wchodziły stosunki cywilnoprawne. Od 1889 r. w wyniku zdecydowanej postawy nowego właściciela dóbr zakopiańskich, polskiego arystokraty z francuskim obywatelstwem,

nie było, poza Franciszkiem Józefem - w jednej osobie cesarzem Austrii i królem Węgier - innej kompetentnej władzy, która by mogła rozstrzygnąć spór między dwoma członami monarchii”. J.M. Roszkowski, Spór o Morskie Oko na tle ksztaltowania się granicy w Tatrach [w:] S. Sierpowski (red.), Władysław Zamoyski..., s. 71.

${ }_{12}$ Warto przypomnieć, że Węgrzy nie zawahali się przed przepędzeniem 4 lipca 1891 r. ze spornego terenu sądowej komisji austriackiej, grożąc austriackim urzędnikom sądowym użyciem ostrej amunicji, Z. Nowak, Władysław Zamoyski a spór..., s. 81 i n. Incydent ten szeroko opisywała prasa i stał się on przedmiotem interpelacji (zob. też przyp. 15).

${ }_{13}$ „Dodatek do nr 14 Kurjera Lwowskiego” z 13.01.1896 r.: ,ugoda musi być wynikiem kompromisu" - tak komentowała prasa decyzję o polubownym załatwieniu granicznego sporu o Morskie Oko: „Wyrok takich sędziów nie może być innym, tylko kompromisowym, według którego obie strony coś ze swoich żądań będą musiały ustąpić”.

${ }^{14}$ A. Mniszek-Tchorznicki, Wspomnienia moje odnośnie do sporu granicznego przy Morskim Oku [w:] J.M. Roszkowski, Walka o Morskie Oko..., s. 153-154. Gadulstwo Badeniego przyczyniło się do zakończenia jego kariery politycznej. W. Łazuga, ,Rządy polskie” w Austrii. Gabinet Kazimierza hr. Badeniego 1895-1897, Poznań 1991, s. 206. O przesadnej czy rozbrajającej szczerości Badeniego: ibidem, s. 65, 120. 
hr. Zamoyskiego, spór o prawo prywatnej własności obszaru nad Morskim Okiem przestał być łagodzony kolejnymi politycznymi ustępstwami ze strony administracji Galicji. Pruski junkier, książę Christian Hohenlohe, i jego urzędnicy natrafili na godnego siebie przeciwnika i zaczęli zdawać sobie sprawę, że bez korzystnego dla Węgier rozstrzygnięcia kwestii granicy politycznej znacząco mogą zmaleć ich szanse na sukces w rozszerzaniu jaworzyńskiej własności prywatnej pruskiego magnata kosztem majętności zakopiańskiej ${ }^{15}$. Konieczność kompromisu była widoczna i z jednej strony powinien on zaspokoić potrzebę realizacji myśliwskich zamiłowań Chrystiana Hohenlohe ${ }^{16}$, a z drugiej - zapewnić Galicji ochronę jej znaczących interesów turystycznych w okolicy Morskiego Oka ${ }^{17}$. Czy wobec tego można się

${ }^{15}$ Prasa w całej monarchii odnotowała bezprecedensowe wydarzenie, gdy funkcjonariusze leśni Hohenlohe i węgierscy żandarmi, pod groźbą użycia broni palnej, 4 lipca 1891 r. przepędzili ze spornego terytorium wykonujących czynności służbowe austriackich urzędników sądowych. Przebieg incydentu: Komisja sadowa kolo Morskiego Oka, „Kurier Lwowski” nr 188 z 9.07.1891 r. Zob. też „Pester Lloyd” nr 188 z 11.07.1891 r., nr 191 z 14.07.1891 r., nr 194 z 17.07.1891 r.; „Neue Freie Presse” nr 9655 z 14.07.1891 r., nr 9666 z 25.07.1891 r.; „Die Presse” nr 191 z 14.07.1891 r.; „Czernowitzer Presse” z 15.07.1891 r.; „Bukowiner Nachrichten” nr 850 z 16.07.1891 r.; „Innsbrucker Nachrichten” nr 161 z 18.07.1891 r.; ,,(Linzer) Tages-Post” nr 171 z 29.07.1891 r.; ,Vorarlberger Volks-Blatt” nr 171 z 30.07.1891 r. Można uznać, że drastyczne i niewątpliwie bezprawne węgiersko-pruskie działanie zainicjowało bardziej zdecydowane żądania aktywnej obrony interesów galicyjskich (np. interpelacja w parlamencie wiedeńskim Apolinarego Jaworskiego) stawiane władzom austriackim. Zob. „Kurier Lwowski” nr 191 z 12.07.1891 r. Warto pamiętać, że wysłana dzięki staraniom Zamoyskiego galicyjska komisja miała „odmierzyć dokładnie granicę upartym Węgrom” („Kurier Lwowski” nr 186 z 7.07.1891 r.). W tym przypadku strona austriacka zamierzała jednostronnie rozstrzygnąc stuletni spór: „Komisja niedaremnie pojechała. W razie uporu przeciwnej strony poprzeć powinna swoje urzędowanie siłą zbrojną” (ibidem). Czy można się dziwić, że samowoli austriackiej odpowiedziano samowolą węgierską?

${ }^{16}$ Do Wiednia, tuż przed pojawieniem się inicjatywy cesarskiej, przyjechał z prywatną wizytą kanclerz Rzeszy, ks. Hohenlohe, z małżonką. Rodzinne spotkanie przed sylwestrem nie musi rodzić podejrzeń, ale gdy wiemy, że pruski gość uzyskał też audiencję u Franciszka Józefa, a następnie spotkał się z premierem Austrii, hr. Badenim? Na obiedzie siedział po prawej ręce cesarza. Zob. „Das Vaterland” nr 358 z 30.12.1895 r. i z tego samego dnia „Wiener Zeitung”, „Salzburger Chronik”, „Montagsblatt (Montags-Revue) aus Bőhmen” nr 424 i inne. Warto przypomnieć informacje (jak się okazało, fałszywe) podawane z dworu w Jaworzynie tuż przed wizją lokalną, że na położone koło Morskiego Oka tereny myśliwskie Christiana Hohenlohe, w czasie obrad sądu polubownego, przybędzie pasjonat polowań, cesarz Wilhelm II („Kurier Lwowski” nr 235 z 25.08.1902 r.). Następnego dnia w „Słowie Polskim” można było przeczytać o pogłosce, że w czasie trwania rozpraw w Grazu „,zjedzie cesarz Wilhelm do ks. Hohenlohego [...]. Pogłoskę tę potwierdził leśnik Hohenlohego, którego szczegółowo o instrukcje wydane na czas polowania wypytaliśmy. Pruski Kaiser ma według jego zapewnień przyjechać do Kasteli w Jaworzynie i zapolować z Hohenlohem pod Żabiem [teren sporny] na kozice” (,Słowo Polskie” nr 414 z 26.08.1902 r.).

${ }^{17}$ Było wówczas oczywiste, że jedynie Galicja jest w stanie zapewnić turystyczną dostępność tych spornych, a najpiękniejszych obszarów Tatr. Na przykład „Kurier Lwowski” nr 250 z 9.09.1897 r. informuje, że społeczność komitatu spiskiego jest zainteresowana sukcesem Galicji w sporze o Morskie Oko: „w przeciwnym razie »samolubny « książę Hohenlohe zabroni publiczności wstępu na terytorjum, podczas gdy hrabia Zamojski uprzejmość wszystkim okazuje”. Natomiast 
wahać, że mamy tu do czynienia z próbą znalezienia uzasadnionego rozwiązania, a może raczej z cyniczną grą politycznych pozorów? Poufnemu i nieformalnemu porozumieniu obu rządów postanowiono nadać bezpieczną dla władz (polityków) formę wyroku sądu rozjemczego. A skoro do zawarcia ugody nieformalnej już doszło, można się było spodziewać działań mających na celu narzucenie niezawisłemu trybunałowi, opartemu na powadze sędziowskiej najwyższych krajowych funkcjonariuszy sądownictwa, wyrokowania zgodnego z poufną umową zawartą między rządami Austrii i Węgier.

\section{UWARUNKOWANIA POLITYCZNE}

Zanim zostaną przedstawione okoliczności uzależnienia trybunału rozjemczego, warto przypomnieć, co zdecydowało o kształcie opartej na permanentnym kompromisie austro-węgierskiej sytuacji politycznej, którą cechował brak wspólnych, dysponujących władzą na obszarze całej dualistycznej monarchii, organów państwowych ${ }^{18}$. Do rozstrzygania spraw dotyczących Przedlitawii i Zalitawii niezbędne były komisje mieszane: „eine gemischte Commission bestehend aus österreichischen und ungarischen Verwaltungs Beamten"19. Zrozumienie postawy rządzących w sporze o Morskie Oko wymaga wzięcia pod uwagę mających miejsce w dualistycznej monarchii wydarzeń politycznych, np. konieczności odnawiania co 10 lat ustrojowej ugody austriacko-węgierskiej ${ }^{20}$, wywołującej spory i protesty sprawy równouprawnienia języka czeskiego, tzw. kwestii wiedeńskiej (Wienfrage) czy reformy wyborczej lub reformy urzędniczej. I to zarówno w czasie podejmowania decyzji o sposobie rozstrzygania sporu o Morskie Oko (1894-1897) ${ }^{21}$,

„Pester Lloyd” z 27.08.1905 r., a więc trzy lata po procesie, podkreśla nieudolność komitatu spiskiego w organizacji turystyki w Tatrach.

18 „W życiu politycznym Austrii wszystko kończyło się na kompromisie” - pisze w swoich wspomnieniach cesarsko-królewski szambelan, Marian Rosco Bogdanowicz, Wspomnienia, t. 2, Kraków 1959, s. 93, 265. Pomijamy tu kompetencje konstytucyjnie realizowane przez wspólne dla obu monarchii ministerstwa spraw zagranicznych, wojny i w tym zakresie skarbu.

19 „Neue Freie Presse. Abendblatt” nr 9666 z 25.07.1891 r. Powołano taką, gdy nad Morskim Okiem groźbą użycia broni palnej Węgrzy przegonili austriacki sąd.

${ }^{20} \mathrm{~W}$ tym czasie spotykamy nawet bardzo drastyczne postulaty rozerwania unii węgiersko-austrackiej: „Przewódca skrajnej lewicy, Gabrjel Ugron, postawił na dzisiejszem posiedzeniu sejmu węgierskiego wniosek, żądający, aby rząd węgierski nie wchodził w żadne rokowania z rządem przedlitawskim w sprawie odnowienia ugody, jako nieparlamentarnym. Prezes ministrów, Banffy, z oburzeniem odepchnął ten niedorzeczny wniosek”. „Kurier Warszawski” nr 10 z 10.01.1896 r.

${ }^{21}$ Syntetyczne przedstawienie problematyki stojącej przed rządem Badeniego ugody (W. Łazuga, ,,Rządy polskie” w Austrii.., s. 71-72), omówienie najważniejszych problemów, którym musiał stawić czoło ten „polski” rząd austriacki, oraz krótkie uwagi na ten temat: „Słowo Polskie” $\mathrm{nr} 4$ z 5.01.1896 r. Nie można też zapominać, że nie tylko rząd austriacki, ale także rząd węgierski borykał się z problemami wewnętrznymi. 
jak i jej realizacji (1897-1902)22. W takiej sytuacji rozpoczynanie dodatkowego konfliktu austriacko-węgierskiego, zwłaszcza w błahej z punktu widzenia polityki obu państw sprawie, nie miało sensu. Z drugiej strony naciski, zwłaszcza ze strony Galicji ${ }^{23}$, a także konieczność ustalenia prywatnych praw własności na spornym obszarze nie pozwalały przeciągać konfliktu przez odwlekanie rozstrzygnięcia. Warto zauważyć, że żaden z rządów nie miał pola manewru - poza ugodą nie istniało rozwiązanie, które satysfakcjonowałoby obie strony sporu. Uznanie słuszności jednego z dwóch wykluczających się żądań, czy to Węgier, czy Austrii, wywołałoby po jednej lub po drugiej stronie wzburzenie. Jakikolwiek kompromis uzgodniony przez rządy też wydawał się nierealny, skoro Galicja uznawała polskość całego otoczenia Morskiego Oka, a Węgrzy, podjudzeni przez Hohenlohego, także domagali się zachowania w granicach swego państwa całego spornego terytorium ${ }^{24}$. Rację miał więc premier Badeni, wskazując już w $1897 \mathrm{r}$. w poufnej rozmowie z przyszłym arbitrem sądu polubownego, że każde rozstrzygnięcie dokonane przez rządy może tylko nasilić ten konflikt ${ }^{25}$. By tego uniknąć, należało znaleźć kogoś, na kogo spadnie odpowiedzialność za podjęcie pożądanej przez władzę decyzji. Innymi słowy, trzeba było znaleźć kandydata na „chłopca do bicia"26.

${ }^{22}$ Por. zarzut wobec rządu austriackiego premiera Kőrbera: wciąż istnieje „wlokący się od niepamiętnych czasów spór czesko-niemiecki, słoweńsko-niemiecki i włosko-niemiecki”, w odpowiedzi na ofertę, by premier podjął się zadania mediatora w konflikcie polsko-ukraińskim, „Kurier Lwowski" nr 225 z 15.08.1902 r.

${ }^{23}$ Zestawienie i charakterystykę prasowych publikacji dotyczących Morskiego Oka, których nasilenie można obserwować od 1891 r., a także innych form aktywności społecznej i politycznej związanych z dokumentowaniem granic wokół Morskiego Oka sporządziła Z. Nowak, Władysław Zamoyski a spór..., s. 79-87.

${ }^{24}$ Tak też, choć z subtelną, ale istotną różnicą, przedstawia to Z. Nowak: „rząd austriacki, mając słuszność za sobą, ustąpić nie mógł, rząd węgierski wprowadzony w błąd przez administrację jaworzyńską ustąpić nie chciał”. Ibidem, s. 87.

${ }^{25}$ To stanowisko obu rządów Badeni przedstawia Tchorznickiemu w lutym 1897 r., tuż po uchwaleniu ustaw parlamentarnych (A. Mniszek-Tchorznicki, Wspomnienia moje..., s. 153-154). Okazuje się, że obawy Badeniego, ówczesnego premiera Austrii, miały racjonalne podstawy, skoro po 5 latach od jego wypowiedzi inny premier Węgier musiał thumaczyć się wobec zarzutów stawianych mu w węgierskim parlamencie: „Następnie przechodzi Szèll [premier Węgier] do sprawy Morskiego Oka i oświadcza, że nie spodziewał się, aby mu właśnie o tej sprawie czyniono zarzuty, ponieważ ustawa, która ją uregulowała, nie pochodzi od niego i ponieważ on sam najmniejszego wpływu na wyrok nie miał. Łatwo jest podnosić skargi, ale opozycja powinna mieć także szacunek dla niezawisłości sędziowskiej”. „Kurier Lwowski” nr 281 z 10.10.1902 r.

${ }^{26}$ Termin Prügelbub wykorzystuje w swoich wspomnieniach Mniszek-Tchorznicki, Wspomnienia moje..., s. 154. 


\section{MIĘDZYNARODOWE SĄDOWNICTWO POLUBOWNE PRZED 1899 R.}

Przy rozpatrywaniu koncepcji rozwiązania sporu o Morskie Oko ważne jest uwzględnienie stanu ówczesnej praktyki wykorzystywania arbitrażu do pokojowego rozstrzygania sporów międzynarodowych, zwłaszcza że podjęcie decyzji o skierowaniu sporu o Morskie Oko przed trybunał arbitrażowy miało miejsce jeszcze przed I pokojową konferencją w Hadze. Natomiast realizacja ustaw parlamentów węgierskiego i austriackiego odbywała się już po przyjęciu I Konwencji o pokojowym załatwianiu sporów międzynarodowych (29 lipca 1899 r.). Wykorzystanie w czasach nowożytnych znanych średniowieczu mechanizmów powoływania organów rozstrzygających metodą pokojową międzynarodowe spory wiąże się niemal powszechnie $\mathrm{z}$ traktatem pokojowym (zwanym traktatem waszyngtońskim ${ }^{27}$ ), zawartym w 1871 r. przez Stany Zjednoczone i Wielką Brytanię (oraz Kanadę). W jego ramach czterokrotnie odwołano się do arbitrażu. Za jego pomocą m.in. zakończono „wojnę świńską", a co najważniejsze, rozstrzygnięto o roszczeniach odszkodowawczych Stanów Zjednoczonych związanych z zarzutami naruszenia neutralności, kierowanymi pod adresem byłej metropoliii ${ }^{28}$ (tzw. roszczenia „Alabama” - ,generally known as the »Alabama« claims”, art. I traktatu ${ }^{29}$. Wykorzystane

${ }^{27}$ Treaty between Her Majesty and the United States of America, signed at Washington, May $8,1871$.

${ }^{28} \mathrm{~W}$ pierwszym wykorzystano klasyczną formę arbitrażu, w której rozstrzygnięcie oddaje się głowie państwa trzeciego - wyrok wydał w 1872 r. cesarz Wilhelm I. Większe znaczenie dla stosunków międzynarodowych miał arbitraż w „sprawie Alabamy”, rozstrzygniętej przez trybunał powołany w sposób, który dał podstawę do kształtowania na konferencjach haskich systemu sądów arbitrażowych.

${ }^{29}$ Stany Zjednoczone uzyskały potwierdzenie części swych roszczeń (odszkodowanie za straty bezpośrednie w zawrotnej wysokości $15 \mathrm{mln}$ dol. w złocie). W traktacie waszyngtońskim określono precyzyjnie strukturę i zasady funkcjonowania sądu polubownego. Wskazano pięć osób pełniących funkcje głowy państwa (prezydent USA, królowa W. Brytanii, król Włoch, prezydent Konfederacji Szwajcarskiej i cesarz Brazylii), które mają powołać każda po jednym arbitrze (w razie, gdyby któraś $\mathrm{z}$ tych osób swego zadania nie wykonała, przewidziano, że o działanie w tym zakresie poproszony zostanie król Szwecji i Norwegii). Ustalono też m.in. prawo do powołania doradców dla każdego arbitra (William Maxwell Evarts służył jako doradca arbitra amerykańskiego). Mocą traktatu ustalono generalne zasady określające neutralność i reguły czasowe ich obowiązywania, a także zasady posługiwania się normami prawa międzynarodowego (art. VI). Nie pozostawiono też żadnej istotnej kwestii poza uregulowaniem traktatowym. Określone w nim zostały nawet zasady dostarczania korespondencji, terminy i miejsce obrad, a także zwolnienie od obowiązku składania na wyroku podpisu przez arbitra, który się nań nie godził („The decision of the Tribunal shall, if possible, be made within three months from the close of the argument on both sides. It shall be made in writing and dated, and shall be signed by the Arbitrators who may assent to", art. VII). Nie dziwi więc, że na wyroku w sprawie Alabamy brakuje podpisu arbitra brytyjskiego. Ustawy zawierające ugodę między Austrią i Węgrami w sprawie arbitrażu o granicę w okolicy Morskiego Oka, nie tylko 
w tym postępowaniu rozwiązania uznane zostały w przyszłości za modelowe, m.in. ze względu na to, że z traktatu z $1781 \mathrm{r}$. wynika, iż całe postępowanie arbitrażowe zależy wyłącznie od woli (umowy) stron. Niezależnie od tych wzorców praktyki światowej warto zauważyć, że pracom przygotowującym rozstrzygnięcie sporu o Morskie Oko towarzyszą na forum międzynarodowym rozmaite działania mające na celu wypracowanie mechanizmów zapobiegania przekształceniom konfliktów między państwami w działania militarne. Zakończyło je zaś przyjęcie przywołanej konwencji ${ }^{30} \mathrm{i}$ jej skorygowanej wersji z $1909 \mathrm{r}$.

Pracom parlamentów węgierskiego i austriackiego nad ustawą realizującą przypisywany przez prasę inicjatywie cesarskiej projekt rozwiązania konfliktu o Morskie Oko równolegle, ale niezależnie, towarzyszyły na terenie monarchii Habsburgów obrady gremiów promujących pokojowe rozstrzyganie konfliktów międzynarodowych. Przywoływano na nich m.in. projekt sądu polubownego w sprawie granicy w Tatrach. I tak w Budapeszcie miał miejsce VII Międzynarodowy Kongres Pokoju (22 września 1896 r.), a po nim (24 września) odbyła się konferencja międzyparlamentarna poświęcona sądom rozjemczym:

Podczas dyskusyi nad pytaniem, jakich środków i dróg należy użyć, aby zapewnić uchwałom kongresu przeprowadzenie i zrealizowanie takowych, wskazał Berzewiczy na próbę załatwienie sporu o Morskie Oko w drodze sądu rozjemczego. Mówca spodziewa się, iż idea ta w końcu zwycięży, pomimo tylu przeszkód i trudności. Konferencya powinna dążyć do stałego sądu rozjemczego, nie zaś do sądu, zwoływanego od przypadku do przypadku³ .

Podobnie 12 grudnia w Wiedniu na V Zgromadzeniu Austriackiego Towarzystwa Przyjaciół Pokoju podkreślano znaczenie planów rozstrzygnięcia sporu o Morskie Oko w drodze arbitrażu ${ }^{32}$. W tej sytuacji nie dziwi, że w czasie obrad w wiedeńskiej Radzie Państwa nad projektem ustawy, w trakcie kolejnej debaty w Izbie nie dyskutowano o samym projekcie, gdyż ustawę o granicy przy Morskim

te, ale wszystkie kwestie pomijają milczeniem, pozostawiając je do decyzji rządów i otwierając drogę do dowolnego, pożądanego przez władzę wykonawczą, z wykluczeniem głowy państwa, ukształtowania relacji rządy - trybunał.

${ }^{30}$ La Conference Internationale de La Paix. La Haye, 18 Mai - 29 Juillet 1899. Scholar select (French Edition) (French) Paperback - August 27, 2016.

${ }^{31}$ I dalej czytamy: „Mówca wnosi rezolucye, wzywającą członków kongresu, aby przez rozpowszechnienie memoryału i dyskusyę w parlamentach, oraz przez popularne przedstawianie sprawy międzynarodowego sądu rozjemczego, takową popierali, a w czasie, mającym się później oznaczyć, przedłożyli w parlamentach wniosek celem zainaugurowania wspólnej akcyi. Pierantoni [kolejny uczestnik debaty] wnosi rezolucyę, aby członkowie kongresu zwrócili się z prośbą do cywilizowanych państw, iżby kwestya międzynarodowych sądów rozjemczych była przedłożoną konferencyi dyplomatycznej”. „Dziennik Krakowski” nr 220 z 25.09.1896 r.

32 „Prager Tagblatt” nr 344 z 14.12.1896 r. 
Oku przyjęto na tej sesji od razu w drugim i trzecim czytaniu ${ }^{33}$. Posłowie przygotowali natomiast dwie niezwiązane bezpośrednio z przedmiotem obrad rezolucje parlamentarne. W pierwszej zalecali rządowi, by w przyszłych międzynarodowych umowach handlowych zawsze zastrzegał powołanie sądu polubownego na wypadek sporu dotyczącego interpretacji lub wykonania umowy, w drugiej - poważne rozważenie (ernste Erwägung) zawarcia z państwami europejskimi porozumień przewidujących w określonych sprawach rozstrzyganie sporów w drodze arbitrażu ${ }^{34}$.

Międzynarodowe sądownictwo polubowne to w tym czasie modny temat w sferach politycznych ${ }^{35}$, a jednocześnie - o czym nie wolno zapominać - instytucja, która dopiero się odradzała i której społeczny odbiór nie zawsze był właściwy, skoro uznawano, że jego celem jest rozstrzygnięcie sporu prawnego, a nie - jak powinno się rozumieć - zlikwidowanie konfliktu ${ }^{36}$. Pozwala to bowiem władzy na takie ukształtowanie sądu, by zapewnić sobie wydanie oczekiwanego wyroku.

${ }^{33}$ „Wiener Zeitung” nr 282 z 4.12.1896 r. Jedyny dyskutant wyznał, że z radością przyjmuje projekt, gdyż dzięki niemu spór o Morskie Oko zostanie w końcu rozstrzygnięty. Ponadto cieszył go fakt, że po raz pierwszy parlament zajmuje się powołaniem sądu polubownego.

${ }^{34}$ Ibidem. Znaczenie obu eksponowano na V Zgromadzeniu Austriackiego Towarzystwa Przyjaciół Pokoju.

35 „Cała prasa tutejsza jest po stronie kongresu i wyraża mu głośno swe sympatye. Jakkolwiek nie można temu kongresowi i w ogóle działalności towarzystw pokojowych przypisywać żadnego pozytywnego znaczenia, to jednak u większości przeważa przekonanie: jeżeli nic nie pomoże, to przynajmniej nie zaszkodzi. A humanitarność jest obecnie modą na Węgrzech. Moda to czynnik potężny, zwłaszcza tam, gdzie to nic nie kosztuje. To też prasa jest teraz stanowczo usposobiona pokojowo, a nawet rząd mógł sobie pozwolić na tanią przyjemność wyrażenia kongresowi swych sympatyj przez usta ministra spraw wewnętrznych Perczela”. „Dziennik Krakowski” nr 219 z 24.09.1896 r.

${ }^{36}$ Tak np. w czasie sporu o Morskie Oko prasa galicyjska uznaje każdą informację o przypuszczalnym galicyjsko-węgierskim kompromisie jako wskazanie na możliwe nadużycie i zaprzeczenie sprawiedliwości. Podkreślmy: w postępowaniu pojednawczym (polubownym, rozjemczym), którego celem jest właśnie znalezienie kompromisu! Tak bezkompromisowo ukształtowane zostały poglądy społeczeństwa: ,Z powodu wiadomości, jakoby istniał w łonie trybunału rozjemczego prąd kompromisowy, a zatem korzystny dla Węgier, otrzymaliśmy szereg listów i protestów. Dla przykładu dwa z nich przytaczamy. Jeden z nich opiewa: »Piszą, że nam grozi kompromis z Węgrami. Niech Bóg broni, żeby nam miała przepaść choćby piędź jedna ziemi naszej, gór naszych, choćby jeden strumyk nasz, a nie to dopiero nasze cudne, cudne 'Morskie Oko'. Po co nam kompromisów, skoro słuszność i sprawiedliwość po naszej stronie [...] Polki protestują przeciw temu, żeby oddać choćby grudkę ziemi polskiej więcej niż się należy! Z głębokim szacunkiem Flora Ogórkówna, Antonina Łużańska, Józefa Olpińska, Laura Olpińska, Antonina Kazimierowicz, L. Ostrowska, [...]«. A oto pismo drugie: $» Z$ przerażeniem wyczytałem, że są pewne względy, ażeby ks. Hohenlohemu polowania nie zepsuć, że może się zrzekniemy części naszych praw do obszarów nad Morskim Okiem. Czy kto kiedy ma jakie względy dla nas? Czy taki Niemiec się kiedy pyta, jeżeli zabiera komu innemu, a zwłaszcza Polakowi ojczystą ziemię? A zresztą, jeżeli temu panu idzie o polowanie na obcem terytoryum, Wydział krajowy może mu wydzierżawić, ale nigdy nie powinien mu dr. Tchorznicki zrzec się praw, słusznie przez Boga nam przypadających! E. Stromenger «”. „Słowo Polskie" nr 439 z 10.09.1902 r. 
Jacek Matuszewski

\section{KONCEPCJE ROZSTRZYGNIĘCIA, INICJATYWA CESARSKA I DWIE USTAWY}

Czy rządom Austrii i Węgier udało się w tym przypadku skutecznie przeprowadzić całą intrygę? Skąpe informacje źródłowe nie pozwalają poznać przebiegu wydarzeń politycznych, które doprowadziły do upoważnienia rządów węgierskiego i austriackiego, aby poddać pod decyzję sądu polubownego spór o granicę galicyjsko-węgierską w Tatrach. Można jednak częściowo odtworzyć proces doprowadzenia do przyjęcia przez oba parlamenty ustaw o ustanowieniu tej granicy w okolicy Morskiego Oka, praktycznie przekazujących władzy wykonawczej obu części monarchii prawo do utworzenia i powołania trybunału, który w Grazu rozstrzygał austriacko-węgierski spór graniczny.

Wiemy, że oba parlamenty - węgierski w 1896 r. i austriacki na przełomie lat 1896 i 1897 - zgodnie z obowiązującą procedurą ustawodawczą przyjęły rządowe projekty ustaw, w których określono sposób rozstrzygnięcia sporu o Morskie Oko. Wiemy też, że obie przyjęte w wyniku tych działań ustawy miały charakter ramowy. Wskazywały jedynie sposób (przez sąd polubowny) i miejsce wyznaczenia granicy (przy Morskim Oku). Natomiast mimo odmiennej praktyki międzynarodowej ${ }^{37}$ ustawodawcy nie zadali sobie trudu, by ustalić organizację trybunału czy określić jego skład i funkcjonowanie. Prawo ukształtowania trybunału rozjemczego, jego struktury, składu, obowiązującej procedury czy prawa, którym arbitrzy mieliby się posługiwać, pozostawiono obu rządom. Ustawodawcy nie przewidzieli tu żadnych ograniczeń ani nie wydali żadnych zaleceń. Nie wskazali nawet, w jakim trybie rządy mają podejmować odpowiednie decyzje. Ustanowiony w drodze ustaw dwóch parlamentów obowiązek okazał się więc przywilejem władzy wykonawczej. Jak się z tego obowiązku wywiązała? Jak wykorzystała ten rozległy przywilej?

Nie dysponujemy żadnym aktem rządowym w tym zakresie. O wszystkich działaniach decydowano w sposób nieoficjalny, w czasie poufnych rozmów, a jedyne oficjalne decyzje stanowiły akty nominacyjne ${ }^{38}$.

W jaki sposób doszło do podjęcia decyzji ustalającej granice państwa, bez ponoszenia jej politycznych kosztów? Proces tworzenia podstawy prawnej i kon-

${ }^{37}$ We wzorcowym arbitrażu brytyjsko-amerykańskim zapisanym w traktacie waszyngtońskim z $1871 \mathrm{r}$. w art. I-X ustalono chyba wszystko, co było niezbędne do funkcjonowania trybunału (uregulowano nawet postępowanie na wypadek śmierci jednego $\mathrm{z}$ arbitrów: „In the case of the death, absence, or incapacity to serve of any or either of the said Arbitrators...").

${ }^{38}$ Mamy podpisaną przez austriackiego prezydenta ministrów nominację na funkcję arbitra, adresowaną do Aleksandra Mniszek-Tchorznickiego, oraz wydany przez Wydział Krajowy 18 marca 1898 r. akt nominacji prof. Oswalda Balzera na stanowisko delegata Wydziału w sporze granicznym. O nominacji pierwszego arbitra węgierskiego dowiadujemy się $\mathrm{z}$ aktu nominacyjnego Tchorznickiego. 
struowania trybunału dla rozstrzygnięcia omawianego sporu można podzielić na trzy etapy:

- do przełomu 1895/96 - okres działań wstępnych, przygotowawczych, przede wszystkim odsuwających w czasie rozstrzygnięcia: to cesarskie „Bądźcie cierpliwi";

- inicjatywa cesarska z początku $1896 \mathrm{r}$. do uchwalenia odpowiedniej ustawy na Węgrzech w 1896 r. i w Austrii w 1897 r.;

- wykonanie obu ustaw - od powołania trybunału po $1902 \mathrm{r}$.

Zakładamy, że rozpatrzenie wszystkich znanych elementów procesu powoływania organu, który miał rozstrzygać spór o Morskie Oko, pozwoli odpowiedzieć na pytanie o stopień niezależności trybunału. Czy, a jeżeli tak, to gdzie w procesie powstawania koncepcji organizacyjnej rozstrzygania sporu można dostrzec czynniki prowadzące do uzależniania sądu polubownego od władzy wykonawczej?

Etap pierw szy. Jego początek należy wiązać z nabyciem ,państwa zakopiańskiego" przez Władysława hr. Zamoyskiego, który zaczął zdecydowanie przeciwstawiać się próbom zajmowania przez ks. Hohenlohe terytorium myśliwskiego, do którego tytuły prywatnej własności przypisywali sobie równocześnie obywatele Galicji ${ }^{39}$. Okres ten zamyka wystąpienie w styczniu 1896 r. cesarza Franciszka Józefa z inicjatywą przygotowania procedury rozstrzygnięcia sporu politycznego między Austrią a Węgrami o granice w okolicach Morskiego Oka. W jej wyniku parlamenty spierających się o granicę państw podjęły uchwały o powołaniu sądu polubownego (parlament węgierski w październiku 1896 r., parlament austriacki w styczniu 1897 r.). Ostatni etap to czas realizacji ustaw parlamentów, który trwał aż do momentu zebrania się trybunału rozjemczego na pierwszym posiedzeniu w Grazu (21 sierpnia 1902 r.).

Wiemy, że międzyrządowe uzgodnienia o powołaniu trybunału rozjemczego zostały poprzedzone długotrwałymi staraniami o ustanowienie stabilnej linii granicznej, podejmowanymi jednak bez skutku przez niemal całe stulecie. Ostatnia próba ugodowego rozstrzygnięcia miała miejsce w 1883 r., ale i wówczas galicyjsko-węgierska komisja mieszana nie doprowadziła do zawarcia ugody.

W pierwszym etapie i rząd węgierski, i austriacki niejednokrotnie były pytane o ten konflikt. I co ciekawe, oba udzielały odpowiedzi sugerujących pomyślne dla pytającego zakończenie sprawy. Tak premier Badeni odpowiadał na posiedzeniu parlamentarnej komisji budżetowej w połowie listopada 1895 r. w Wiedniu: „Co do głównej sprawy granicznej Morskiego Oka, to rząd węgierski gotów jest przy-

39 Przebieg sporu przedstawia Z. Nowak, Władysław Zamoyski a spór..., passim. Główne elementy sporu w XIX w. można znaleźć w „Kurierze Lwowskim” nr 204 z 24.07.1901 r. (za „Przeglądem Zakopiańskim"). 


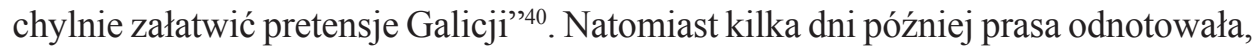
że węgierski „rząd odpowiedział wczoraj (21 listopada) na interpelację w sprawie Morskiego Oka, że sprawa zakończy się zapewne zwycięstwem Węgrów"41. Po kilku kolejnych dniach pojawiła się inna informacja o stanie sporu:

[...] doniesienie, jakoby referent austrjacki w sprawie Morskiego Oka zgadzał się $\mathrm{z}$ referentem węgierskim w tej sprawie, jest mylne. Omyłka pochodzi zapewne z mylnego zrozumienia wiedeńskiej korespondencji »Kurjera Warsz.«, w której jedynie stwierdzono, że obaj referenci ukończyli już zbiór dokumentów, że te dokumenty podczas odbytej w Wiedniu konferencji przepatrzyli i że obecnie zamierzają odbyć w czerwcu przyszłego roku komisję na miejscu. $Z$ tego nie wynika, jakoby już zgadzali się w zapatrywaniu na samą rzecz ${ }^{42}$.

O decyzję w tym zakresie występowano nawet do samego cesarza.

Wiemy, że planowano powołanie komisji mieszanej, która miała przygotować odpowiednie porozumienie. „Neue Freie Presse” nr 9666 z 25 lipca 1891 r., informując o zdecydowanej nocie premiera Austrii, hrabiego Taaffe, do premiera Węgier w sprawie nadużyć władz węgierskich nad Morskim Okiem, pisze, że w konsekwencji austriacko-węgierska komisja mieszana „,bestehend aus österreichischen und ungarischen Verwaltungs-Beamten", uda się na teren wydarzeń dla rozpatrzenia konfliktu między sądem galicyjskim a węgierską żandarmerią. Jak podaje oficjalny „Wiener Zeitung”, według informacji ze Lwowa ma zostać także powołana komisja mieszana złożona z przedstawicieli Węgier i Austrii, by naradzić się co do przynależności państwowej Morskiego $\mathrm{Oka}^{43}$. Miałby to być organ o charakterze administracyjnym, a wchodzący w jego skład arbitrzy powołani do tej komisji powinni mieć uprawnienia sędziów przysięgłych, to znaczy mogliby kierować się zasadą słuszności czy racjonalności, niekoniecznie sięgając do przepisów prawa. Przewidywano, że przygotowana przez komisję propozycja zostanie przedsta-

40 „Kurier Lwowski” nr 318 z 16.11.1895 r. Wkrótce (25 stycznia 1896 r.) kolejną interpelację w tej sprawie składa tym razem w Sejmie Krajowym poseł Bojko („Kurier Lwowski” nr 29 z 29.01.1896 r.). Wcześniej hr. Raczyński składał interpelacje do rządu w sprawie uregulowania granicy koło Morskiego Oka, „Wiener Zeitung” nr 257 z 7.11.1890 r. O „pośpiech w złożeniu i zebraniu mięszanej komisji mającej ów spór rozsądzić” systematycznie występował marszałek krajowy, ks. Sanguszko, do przybywających do Lwowa kolejnych austriackich ministrów („Gazeta Narodowa" nr 225 z 12.09.1894 r.). Interpelacje w sprawie Morskiego Oka składano przy różnych okazjach, np. na interpelacje z 7 i 25.11 .1901 r. oraz 9.12.1901 r. łącznie odpowiadał w marcu 1902 r. premier Austrii (,Wiener Zeitung” nr 227 z 19.03.1902 r.), ponownie o losy sporu o Morskie Oko pytał Władysław hr. Koziebrodzki („Wiener Abendpost” nr 221 z 27.09.1892 r.).

${ }_{41}$ „Kurier Lwowski” nr 325 z 23.11.1895 r. O złożeniu interpelacji w sprawie sporów granicznych węgiersko-austriackich i próbie zabrania przez Austrię terytorium węgierskiego informuje „Pester Lloyd” nr 229 z 5.10.1895 r.

42 „Kurier Lwowski” nr 336 z 4.12.1895 r.

43 „Wiener Zeitung” nr 250 z 31.10.1893 r. 
wiona do akceptacji przez konstytucyjne organy władzy monarchii (parlamenty lub rząd). Informację o takiej koncepcji odnotowano kilkakrotnie. We wrześniu 1894 r. cesarz, przyjmując na Wystawie Krajowej we Lwowie deputację z gmin Białki i Zakopanego w sprawie granicy przy Morskim Oku, zapowiedział: „,niebawem komisja mięszana się zbierze i rozpatrzy tę sprawę, należy więc wyroku jej cierpliwie czekać"44. Na podstawie dostępnych informacji można stwierdzić, że w tym czasie rozważania nad problemem Morskiego Oka wiązały się z koncepcją ponownego powołania komisji mieszanej, która na podstawie zgromadzonych przez oba rządy materiałów zaproponuje odpowiednią, kompromisową decyzję, pozwalającą na ostateczne zamknięcie sporu granicznego nad Morskim Okiem. Także rozpoczynająca kolejny etap inicjatywa cesarska zawierała propozycję rozwiązania konfliktu na drodze powołania komisji mieszanej.

Etap drugi. Jedyną formą rozwiązania sporu granicznego między państwami była ugoda (w przypadku sporu między Austrią a Węgrami absurdalna byłaby bowiem ewentualność sięgnięcia po środki militarne). Problemem było tylko ustalenie postępowania, w jakim do zawarcia tej ugody miało dojść: komisja mieszana, mediacja czy postępowanie polubowne. Zgodnie z relacjami prasowymi propozycja cesarska miała zakładać odwołanie się najpierw do komisji mieszanej, której uzgodnioną decyzję powinny następnie zatwierdzić władze obu państw, a na wypadek braku porozumienia - orzeczenie powinien wydać cesarz (lub wskazana przezeń osoba) jako superarbiter. To dodatkowe rozwiązanie najwidoczniej uznano ostatecznie za mało roztropne. Z jednej strony, jak później wskazano w uzasadnieniu składanego do Rady Państwa rządowego projektu odpowiedniej ustawy, tego rodzaju komisje mieszane powoływane uprzednio (w latach 1837, 1858, 1883) zakończyły się niepowodzeniem, a prowadzone wówczas przez oba rządy negocjacje wykazały, że nadal nie ma szans na znalezienie w takim trybie oczekiwanego rozstrzygnięcia ${ }^{45}$. Takie konsekwencje przyjmowanego rozwiązania wskazywał już krakowski „Czas”: „rząd austryacki, opierając się na bogatym materiale aktów, musiał obstawać przy prawach Galicyi, rząd węgierski zaś z zasady ustąpić nie chciał" 46 . Z drugiej strony powierzenie Franciszkowi Józefowi roli superarbitra (bądź prawa wskazania osoby na tę funkcję) nadawałoby władcy pozakonstytucyjne kompetencje. Co więcej, otoczenie cesarza musiało sobie w końcu zdać sprawę, że zaangażowanie Franciszka Józefa w rozstrzyganie kompromisu (czy jako su-

${ }^{44}$ „Cesarz miał odpowiedzieć, że się gorąco zajmuje tą sprawą, że wkrótce zbierze się komisya dla niej i uspokoił górali, że jeżeli słuszność po ich stronie - krzywdy im wyrządzić nie da”. „Gazeta Narodowa" nr 224 z 11.09.1894 r.

45 „Im Laufe des letzten Jahres zwischen den beiderseitigen Ministerien des Innern”. „Wiener Abendpost” nr 226, dodatek do „Wiener Zeitung” z 1.10.1896 r., s. 11.

46 „Czas” nr 6 z 9.01.1896 r. Ten sam tekst opublikował np. „Dodatek do nr 14. Kuriera Lwowskiego" z 13.01.1896 r. 
perarbitra, czy jako osoby decydującej o wyborze takiego sędziego - jak to ujęto w propozycji) wiązałoby się z niekorzystnymi dla wizerunku cesarza konsekwencjami. Kompromis wymaga ustępstw. Kompromis narzucony przez superarbitra sprawi zaś, że każda strona będzie łączyć poczynione ustępstwo (w tym przypadku utratę części spornego obszaru) z arbitrem. Dlatego między styczniem a wrześniem 1896 r. doszło do zmiany początkowej decyzji. Nie sposób, bez niemożliwych dziś do przeprowadzenia w zasobach austriackich i węgierskich gruntownych studiów archiwalnych, o ile takie materiały tam się znajdują, rozstrzygnąć, w jaki sposób do tego doszło. W każdym razie w toku prowadzonych w tym okresie prac nad projektem odpowiedniej ustawy ostatecznie przyjęto, że decyzje w sprawie granic podejmie nie komisja mieszana, lecz sąd rozjemczy.

Według informacji prasowych na przełomie 1895 i 1896 r., najpóźniej w pierwszych dniach stycznia 1896 r., miały miejsce rozmowy międzyrządowe w sprawie Morskiego $\mathrm{Oka}^{47}$. Przygotowywane przez władze Austrii i Węgier decyzje nie przyjęły jednak formy aktów pisanych ${ }^{48}$. Podstawą działania przewidywanego do powołania organu miała być austriacko-węgierska ugoda wyrażona $\mathrm{w}$ formie dwóch równobrzmiących ustaw, ustalających, że decyzję w sprawie granicy przy Morskim Oku ma podjąć sąd polubowny. Konspiracyjny charakter uprawianej przez Badeniego, jako premiera Przedlitawii, polityki nie pozwala bliżej poznać przebiegu rozmów w tej kwestiii ${ }^{49}$. Można jednak sięgnąć do relacji prasowych i na tej podstawie odtworzyć te wydarzenia polityczne.

Początkowo, w styczniu 1896 r., przekazana została opinii publicznej wiadomość, że cesarz wystąpił z inicjatywą przygotowania odpowiedniej ugody, którą

${ }^{47}$ Od 24 października do 1 listopada 1895 r. odbywały się wspólne narady w sprawie referatów przygotowanych przez obie strony. Referat austriacki radcy ministerialnego Henryka Róży liczył 400 stron. „Nowa Reforma” nr 277 z 1.12.1895 r.

${ }^{48} \mathrm{Na}$ konspiracyjny przerost relacji austriacko-węgierskich za czasów gabinetu Badeniego zwraca uwagę W. Łazuga, „Rzady polskie” w Austrii..., s. 71-72: „Niestety, nie wszystko jest tu jasne, a raczej jasne jest mało co. Z konferencji w »cztery oczy « - zapewne najciekawszych - o ile wiadomo, żadnych materiałów nie ma”. Por. Wstęp, ibidem, s. 6, czy w innym miejscu: „Dyskrecja była tu tak daleko posunięta, że L. Biliński [minister w rządzie Badeniego] skarży się w pamiętnikach, że nieraz nie mógł dowiedzieć się, o czym Badeni rozmawiał z Banffym [węgierski premier]". Ibidem, s. 218. W tej sytuacji wskazane jest podkreślenie informacyjnych walorów prasy (s. 8).

49 „Budapeszt 4 stycznia. Minister spraw wewnętrznych Perczel odjechał wczoraj do Wiednia w sprawie Morskiego Oka” („Słowo Polskie” nr 3 z 4.01.1896 r.). We wtorek, 7 stycznia, informowano: „W sprawie Morskiego Oka w niedzielę i w poniedziałek odbywały się narady między Banffym i Perczelem z jednej a Badenim z drugiej strony” („Słowo Polskie” nr 5 z 7.01.1896 r.), a „Kurier Lwowski” dodaje: „Przyszło do porozumienia w tej kwestji, mianowicie zgodzono się na sąd polubowny, którego zadaniem będzie stanowczo sprawę załatwić. Składu sądu polubownego jeszcze nie ustalono” („Kurier Lwowski” nr 8 z 8.01.1896 r.), co ponownie skorygowano: „W sprawie Morskiego Oka donoszą do Dziennika Polskiego, iż sąd polubowny, mający wreszcie załagodzić spór, będzie się składać z czterech członków obu najwyższych trybunałów, którzy sami wybiorą sobie piątego członka” („Słowo Polskie” nr 7 z 9.01.1896 r.). 
miała opracować specjalnie powołania komisja mieszana ${ }^{50}$. Propozycja została ochoczo i zgodnie przyjęta przez oba zaangażowane w spór rządy ${ }^{51}$. Nie ma w tym nic dziwnego, skoro w ramach obydwu Ministerstw Spraw Wewnętrznych od ponad roku prowadzone były prace nad przygotowaniem odpowiedniego rozstrzygnięcia. Projekt cesarski, nieopublikowany, wyciekł do prasy i w korespondencji „Kuriera Warszawskiego" z Wiednia przedstawiono go opinii publicznej w następujący sposób:

Postępowanie będzie zatem następujące: oba rządy wyznaczą po jednym arbitrze; obustronni referenci przedstawią im stosy aktów i swoje wnioski. Wyrok, który arbitrzy wydadzą, będzie ostateczny, bez apelacji, będzie to zaś wyrok innej natury, niż wyrok sądowy. Arbitrzy, mający zupełne pełnomocnictwo, zajmują stanowisko sędziów przysięgłych, którzy kierują się nietylko samą literą ustaw, ale mają i prawo i obowiązek zważać na wszelkie względy słuszności, na historję, tradycję, na uczucia stron, na stosunki turystyczne ${ }^{52}$.

Dostrzegamy tu jeszcze ideę powołania dwuosobowej komisji mieszanej, złożonej z przedstawicieli Austrii i Węgier (po jednym), której zadaniem będzie znalezienie kompromisu, pozwalającego na ostateczne ustalenie linii granicznej w okolicach Morskiego Oka: „Wyrok takich sędziów nie może być innym, tylko kompromisowym, według którego obie strony coś ze swoich żądań będą musiały ustąpić". Podstawą decyzji miały być materiały przedstawione przez reprezentujących oba spierające się państwa referentów, którzy powinni przygotować odpowiednie wnioski. Inicjatywa cesarska miała też przewidywać fazę dodatkową, na wypadek gdyby owi „,sędziowie” nie mogli uzgodnić stanowiska: „Gdyby wszelako pomiędzy nimi jeszcze wątpliwości powstały i różnice zdań, w takim dopiero razie okazałaby się potrzeba powołania trzeciego sędziego, jako superarbitra". Miałby nim zostać cesarz albo wybrany przez niego jeden z kandydatów przedstawionych przez rządy ${ }^{53}$. W razie braku porozumienia komisja mieszana powinna więc prze-

${ }^{50}$ Nie ma wątpliwości, że inicjatywa cesarska miała charakter wtórny wobec działań rządów: „Budapeszt 7 stycznia. Wedle Bud. Corespond. ułożyli się prezydent ministrów hr. Badeni z węgierskim ministrem spraw wewnętrznych, aby sprawę »Morskiego Oka« oddać do ostatecznego załatwienia sądowi rozjemczemu, którego skład jednak dopiero później, znowu po wzajemnem porozumieniu, miałby być złożonym”. „Słowo Polskie” nr 5 z 7.01.1896 r.

${ }^{51}$ „Kurier Warszawski” z 7.01.1896 r.: „Kwestia Morskiego Oka wchodzi w okres rozstrzygający. Cesarz wyraził życzenie, aby załatwiona była nie w drodze procesu, lecz sądu polubownego. Ministrowie obu połów monarchii, spełniając życzenia cesarza, zgodzili się już na sąd polubowny. Prawdopodobnie cesarz proszony będzie na superarbitra".

52 Publikację z „Kuriera Warszawskiego” przedrukowuje z drobnymi zmianami „Kurier Lwowski” z 13.01.1896 r. (dodatek do nr 14); zob. też „Die Presse. Abendblatt” nr 14 z 15.01.1896 r., s. 2.

${ }^{53}$ Tak „Die Presse. Abendblatt” nr 14 z 15.01.1896 r., s. 2; natomiast „Kurjer Warszawski” informuje, że kandydatów tych cesarzowi mieliby wskazywać obaj arbitrzy. 
kształcić się w sąd polubowny (nie wiadomo, czy jedno-, czy trzyosobowy), który miałby przygotować ostateczne rozstrzygnięcie.

Niełatwe było ustalenie charakteru orzeczenia. Z jednej strony wskazano, że wyrok „będzie ostateczny, bez apelacji”, z drugiej że „Wyrok będzie w Austrji prawomocnym odrazu, t. j. cesarz i rząd go zatwierdzą. Na Węgrzech będzie proceder nieco dłuższy, gdyż konstytucja wymaga, żeby wszelkie terytorjalne i graniczne sprawy przedstawiane były parlamentowi. Rząd przeto wyrok w formie projektu do ustawy przedstawi, a po przyjęciu go przez parlament dopiero go król węgierski zatwierdzi”. Trudno zgodzić się z twierdzeniem o prawomocności decyzji, gdy jednocześnie zastrzega się konieczność jej zatwierdzenia. Równie niekonsekwentne jest wskazanie cesarza jako superarbitra z wymogiem, by cesarz Austrii i król Węgier (a zatem trzykrotnie występuje tu ta sama osoba) zatwierdzał własny wyrok.

Niezbyt zrozumiałe są też wywody, w których redakcja warszawskiej gazety próbuje wskazać, jak cenna jest cesarska inicjatywa:

Za pośrednictwo winne są obie strony wdzięczność cesarzowi; droga procesu byłaby jeszcze całe lata trwała, byłyby rekursy itd., gdyby wyrok jedną lub obie strony nie zadowalniał. A z góry można przypuszczać, że wyrok, wydany wyłącznie według procedury sądowej, nie byłby żadnej strony zadowolił, zresztą możność rekursów, apelacyj, nieważności, restytucyj sprawiłaby sama przez się, że obie strony starałyby się wszelkie dopuszczalne sposoby wyzyskać i wyczerpać. Sprawaby się ciągnęła i w każdym razie byłaby pozostawiła przykry osad.

Trudno rozstrzygnąć, czy mamy tu do czynienia z wypowiedzią celowo wprowadzającą w błąd czytelnika, czy też autor po prostu się nad nią nie zastanowił:

Rządy, władze nie byłyby przecież mogły nic innego przedsiębrać, jak tylko stosować przepisy, dla drogi procesu obowiązujące. Na szczęście wola najwyższa panującego po obu stronach, w obu krajach, spowodowała zwrot najsłuszniejszy, który też załatwienie sprawy przyśpieszy. Jest to także jedno z preludjów do odnowienia ugody z Węgrami.

Przypomnijmy: droga sądowa (,procesowa”) w takim sporze w ogóle nie istniała!

Etap trzeci. Gdy doszło do wprowadzenia inicjatywy cesarskiej na drogę ustawodawczą obu monarchii, z opublikowanego w „Wiener Zeitung” uzasadnienia do zgłoszonego przez rząd austriacki 1 października 1896 r. na 511. posiedzeniu wiedeńskiej izby poselskiej projektu ustawy ${ }^{54}$ dowiadujemy się, że przedkładany projekt jest równobrzmiący z projektem przedłożonym niedawno sejmowi węgierskiemu i ma doprowadzić do ustalenia granicy, której - jak podkreślono - dotąd

\footnotetext{
${ }^{54}$ „Wiener Abendpost. Beilage zur Wiener Zeitung” nr 226 z 1.10.1896 r., s. 11.
} 
tam nigdy nie ustalono, że podejmowane w latach 1837, 1858 i 1883 przez komisje mieszane działania nie przyniosły oczekiwanego skutku, a próby negocjacji z ostatniego roku w obu Ministerstwach Spraw Wewnętrznych pokazały daremność dalszych usiłowań. Wskazano też, że z uzgodnień obu stron wynika, iż w skład mającego być powołanym trybunału wejdzie po jednym wyższym funkcjonariuszu sądownictwa Austrii i Węgier, którzy wybiorą superarbitra spoza monarchii. Wynika z tego, że odpowiednie ustalenia już zostały poczynione, ale o żadnej z tych kwestii w ustawie mowy nie ma ${ }^{55}$.

Odpowiednie uzgodnienie rządowe wywołało oczekiwaną akcję węgierskiego parlamentu w Budapeszcie ${ }^{56}$ i austriackiej Rady Państwa w Wiedniu ${ }^{57}$. W styczniu tego roku doszło do istotnej zmiany koncepcji rozstrzygnięcia sporu. Uzgodniono,

${ }^{55}$ W sierpniu 1902 r. przypomina to „Kurier Lwowski (nr 225 z 15.08 .1902 r.): „Wreszcie powstała myśl załatwienia sprawy przez ustanowienie osobnego międzynarodowego sądu rozjemczego. W październiku 1896 r., jako król Węgier, a w styczniu 1897 r. jako cesarz Austrji, podpisuje Franciszek Józef I dwie jednobrzmiące ustawy, według których z każdej strony powołają rządy po jednym arbitrze $z$ najwyższych urzędników sądowych danych krajów; ci dobrawszy sobie superarbitra z poza państwa Austro-węgierskiego, mają wydać wyrok ostateczny". To są ustalenia z uzasadnienia projektu, a nie z ustawy.

${ }^{56}$ Projekt ustawy o powołaniu sądu polubownego węgierski minister spraw wewnętrznych przedstawił w węgierskiej Izbie niższej Parlamentu już 3 września 1896 r. („Pester Lloyd” nr 214 s. 13). Projekt ten został przyjęty przez Izbę niższą 12 września 1896 r. („Wiener Zeitung” nr 212 z 13.09.1896 r.), 24 września znalazł się w Izbie Panów, przez którą został przyjęty 30 września, „Pester Lloyd” nr 232 (s. 2) i 238 (s. 10). W polskiej literaturze pokutuje błędne przekonanie, że ustawa węgierska została przyjęta w 1897 r. (por. J.M. Roszkowski, Spór o Morskie Oko [w:] idem, „Zapomniane Kresy”. Spisz, Orawa, Czadeckie w świadomości i działaniach Polaków 1895-1925, Nowy Targ 2018, s. 83) i że to Węgrzy opóźniali prace nad powołaniem sądu.

57 Jak podał „Kurier Lwowski” w korespondencji z Wiednia z 1 października: „Na dzisiejszem posiedzeniu Izby wniósł rząd projekt ustawy w sprawie załatwienia sporu o Morskie Oko przez sąd rozjemczy” („Kurier Lwowski” nr 274 z 2.10.1896 r.). Ostatecznie projekt był dyskutowany 3 grudnia 1896 r. („Wiener Zeitung” nr 282 z 4.12.1896 r.). Drugie i trzecie czytanie w Izbie Panów miało miejsce 18 stycznia 1897 r. i projekt został przyjęty bez debaty („Pester Lloyd” nr 16 z 19.01.1897 r., s. 3; „Wiener Abendpost” nr 13 z 28.01.1897 r.). Podpis cesarza złożony został kilka dni później (25.1): „Ustawa z dnia 25 stycznia 1897, o ustanowieniu granicy pomiędzy Galicyą a Węgrami przy tak zwanem »Morskiem Oku« w górach Tatrzańskich. Za zgodą obu Izb Rady państwa postanawiam co następuje: §. 1. Upoważnia się Rząd, żeby ustanowienie granicy pomiędzy powiatem nowotarskim (Galicya) a komitatem spiskim (Węgry) przy tak zwanem »Morskiem Oku« (po węgiersku halastó) poddał pod decyzje sądu polubownego zwołać się mającego i żeby w porozumieniu z Rządem królewsko węgierskim poczynił odpowiednie kroki w celu utworzenia tegoż sądu polubownego. §. 2. Wykonanie ustawy niniejszej poruczam Ministrowi spraw wewnętrznych, Ministrowi sprawiedliwości i Ministrowi skarbu. Wiedeń, dnia 25 stycznia 1897. Franciszek Józef r. w. [ręką własną] Badeni r. w. Biliński r. w. [Leon, 1846-1923, minister skarbu w gabinecie Badeniego] Gleispach r. w. [Jan Nepomucen, 1840-1906, minister sprawiedliwości w gabinecie Badeniego]”. Dziennik ustaw państwa dla królestw i krajów w Radzie państwa reprezentowanych. Część IX - Wydana i rozesłana 28. stycznia 1897, s. 57-58. 
że decyzję w sprawie konfliktu podejmie sąd polubowny, powołany na podstawie dwóch odrębnych ustaw, przyjętych przez parlamenty, a podpisanych przez Franciszka Józefa, jako króla Węgier i jako cesarza Austrii - 25 stycznia 1897 r. ${ }^{58}$ Co istotne, oba te akty przekazywały pełnię kompetencji do ustalenia składu, struktury i procedury przewidywanego do powołania organu obu rządom ${ }^{59}$. Do składu sądu rząd austriacki powołał Aleksandra Mniszek-Tchorznickiego ${ }^{60}$, a rząd Węgier Aleksandra Vértesyego, prezesa Trybunału w Budapeszcie ${ }^{61}$, którego w lipcu 1900 r. zastąpił Koloman Lehoczky ${ }^{62}$. Sędziom tym nakazano ${ }^{63} \mathrm{w}$ uzgodnieniu ze swoimi mocodawcami wybrać superarbitra. Trudności z porozumieniem, po upadku kilku kandydatur, doprowadziły w końcu do przekazania tego obowiązku osobie trzeciej, gdyż o wyznaczenie superarbitra arbitrzy poprosili prezydenta Konfederacji Szwajcarskiej ${ }^{64}$. Wskazał on swego rodaka, prawnika, dr. Johanna Winklera, który ostatecznie uzyskał rządową nominację na tę funkcję ${ }^{65}$.

${ }^{58}$ Jednak jeszcze w akcie nominacji Balzera z 18 marca 1898 r. na stanowisko delegata Wydziału Krajowego mowa jest o komisji mieszanej.

59 1897. évi II. Törvénycikk a Magyarország és Ausztria közt Szepes vármegye és Gácsország szélén, az ugynevezett Halastó körüli területen, az országos határvonalnak választott biróság által leendő megállapitása tárgyában. 1. § A ministerium felhatalmaztatik, hogy Magyarország és Ausztria közt Szepes vármegye és Gácsország szélén, az ugynevezett Halastó körüli területen, az országos határvonal megállapitását választott biróság döntése alá bocsáthassa és ezen választott biróság alakitása és kiküldése iránt az osztrák kormánynyal egyetértőleg intézkedjék. 2. § Ezen törvény végrehajtásával a ministerium bizatik meg (https://net.jogtar.hu/ezer-ev-torveny?docid=89700002. TV\&searchUrl=/ezer-ev-torvenyei\%3Fpagenum\%3D34) [II. ustawa z 1897 r. w sprawie powołania sądu do wyznaczenia granicy państwowej między Węgrami a Austrią na granicy Żupanii Spiskiej i Galicji, na obszarze wokół tzw. Halastó [Morskie Oko]. § 1 Upoważnia się Rząd do oddania decyzji o ustanowieniu granicy państwowej między Węgrami a Austrią na granicy Żupanii Spisz i Galicji, na obszarze wokół tzw. Morskiego Oka, trybunałowi, mającemu być powołanym w uzgodnienia $\mathrm{z}$ austriackimi władzami. § 2 Wykonanie ustawy powierza się Rządowi].

${ }^{60}$ A. Barzycka-Paździor, Tchorznicki Mniszek [w:] Polski Słownik Biograficzny, t. 53/1, z. 216, Warszawa - Kraków 2019, s. 35-37.

${ }^{61}$ Ten złamał nogę i ze względu na komplikacje zdrowotne po roku braku aktywności złożył dymisję. A. Mniszek-Tchorznicki, Wspomnienia moje..., s. 163-165. Ze wspomnień tych wynika, że decydujący wpływ na powołanie uczestników procesu mieli austriaccy i węgierscy politycy. O prawie rządów do decydowania w sprawie obsady stanowisk w sądzie rozjemczym mówi premier austriacki, „Pester Lloyd” nr 13 z 15.01.1902 r.

${ }_{62}$ A. Mniszek-Tchorznicki, Wspomnienia moje..., s. 165.

${ }_{63}$ Tak wynika z aktu nominacyjnego Tchorznickiego.

${ }^{64}$ A. Mniszek-Tchorznicki, Wspomnienia moje..., s. 169.

${ }^{65}$ Co ciekawe, $§ 1$ statutu sądu rozjemczego, przyjętego w kwietniu 1902 r. (już po powołaniu superarbitra), przewidywał, że superarbitra mają wybrać arbitrzy i o takiej procedurze czytamy w wyroku trybunału: „Urząd przewodniczącego objął wskutek wyboru sędziów rozjemczych prezydent szwajcarskiego trybunału związkowego Dr. Jan Winkler" [Das Amt des Obmannes hat zufolge der auf ihn gefallenen Wahl der Schiedsrichter der Präsident des schweizerischen Bundesgerichtes Jur. Dr. Johannes Winkler übernommen], co według wspomnień Tchorznickiego nie jest prawdą. O faktycznej zmianie zasad wyboru superarbitra pisze też „Pester Lloyd” z 15.01.1902 r. 
Uzależnienie decyzji o wyborze superarbitra od zgody rządów należy wiązać z jego szczególną pozycją, przyznaną mu w postępowaniu polubownym. Statut tylko jemu pozwalał prowadzić posiedzenia sądowe, przesłuchiwać świadków czy podejmować decyzje procesowe. Do jego uprawnień jednak należało przede wszystkim rozstrzyganie sporu co do mającego zapaść orzeczenia:

Jeśli zapatrywania obu sędziów rozjemczych względem mającego zapaść wyroku się nie zgadzają, może przewodniczący zażądać, aby mu każdy piśmiennie podał swoje uzasadnione wotum. Przewodniczący dyrymuje [rozstrzyga - J.M.], następnie piśmiennie $\mathrm{z}$ włączeniem własnego uzasadnienia ${ }^{66}$.

Zatem to Szwajcar, Jan Winkler, faktycznie decydował o treści wyroku w sprawie Morskiego Oka. Wzmocnieniu jego ,życzliwości” dla rządów austriackiego i węgierskiego niewątpliwie służyły honory okazywane przez władze Galicji superarbitrowi, przyjęcia organizowane na jego cześć czy sprowadzenie do Krakowa w czasie „naoczni” przyjaciela Winklera z lat młodości. Warto też wspomnieć o wysokim honorarium, jakie mu przyznano ${ }^{67}$. O uznaniu swej podległości świadczy też złożona przed wydaniem wyroku wizyta Winklera w Wiedniu u cesarza i premiera Węgier ${ }^{68}$.

Pewne wskazówki zawiera w tym zakresie także akt nominacji austriackiego arbitra, dr. Aleksandra Mniszek-Tchorznickiego, sporządzony i podpisany przez premiera Badeniego ${ }^{69}$. Przygotowując ten akt, premier powołał się na podstawę prawną (ustawa z 25 stycznia 1897 r.). Następnie poinformował, że Tchorznicki zostaje powołany do pełnienia funkcji sędziego w sprawie o granice przy Morskim Oku i że rząd węgierski też już powołał ze swej strony arbitra (Aleksandra Vertesyego). I dalej, że obaj arbitrzy mają przygotować statut sądu rozjemczego, wybrać superarbitra i powiadomić o tym premiera, że Ministerstwo Spraw Wewnętrznych dostarczy zgromadzone materiały (Karten und Buchmaterials) do wskazanego miejsca $^{70}$. Zwraca uwagę silne eksponowanie przez podpisującego akt Badeniego niezależności trybunału, i od niego, i od jego urzędników, zarówno co do procedury,

${ }^{66}$ „Dziennik Poznański” nr 198 z 28.08.1902 r.

67 Wyniosło ono 100 tys. koron, „Praca - Tygodnik Ilustrowany” nr 38 z 21.09.1902 r., s. 990. Suma ta stanowiła ca 1/10 kwoty, za jaką Zamoyski wylicytował całe swe zakopiańskie dobra.

68 „Grazer Volksblatt” nr 411 z 9.09.1902 r., s. 5. Informację tę potwierdzono następnego dnia: „Zur Meeraugenfrage. Wien, 9. September. Der Bundesgerichtspräsident, Obmann der Meeraugenkommission Dr. Winkler ist heute hier eingetroffen” („Grazer Volksblatt” nr 412, s. 9). Zaś „Grazer Tagblatt” nr 249 z 10.09.1902 r., s. 17 pisał: „Er wurde vom Keiser in besonderer Audienz empfangen. Der Keiser dankte Dr. Winkler für seine Mühewaltung un unterhielt sich über Schweizer Angelegenheiten Und die·Meeraugenfrage".

${ }^{69}$ Opis reskryptu nominacyjnego prezydenta ministrów Badeniego przedstawia także A. Mniszek-Tchorznicki, Wspomnienia moje..., s. 154-155.

${ }^{70}$ Akt nominacji w materiałach Aleksandra Mniszek-Tchorznickiego w Muzeum w Sanoku. 
jak i wyroku ${ }^{71}$. Czy wiadomo, co kryje się za tymi deklaracjami? Relacje z rządem przedstawia w swoich wspomnieniach sam nominowany. Można odnieść wrażenie, że austriacki arbiter nie kryje zależności sądu od rządów, np. przy ustalaniu osoby superarbitra węgierski arbiter sugerował, ,że rządom odpowiadałby może więcej członek stanu sędziowskiego jako superarbiter ${ }^{72}$, na wypadek, gdyby oba rządy rzeczywiście uznały wybór sędziego jako najstosowniejszy"73 lub ,że oba rządy bardzo sobie życzą, aby ta decyzja [arbitrów] wkrótce zapadła" ${ }^{\text {"4 }}$. Charakterystyczna $\mathrm{w}$ tej mierze jest zaproponowana przez Winklera zmiana formy finansowania trybunału ${ }^{75}$ i natychmiastowy raport arbitrów do swoich rządów: „O tym wyniku konferencji donieśliśmy, Lehoczky i ja, naszym rządom, żądając wskazówek, co się ma stać z kosztami postępowania..." ${ }^{.76}$. W innym miejscu Tchorznicki wskazuje, że decyzje arbitrów wymagały zgody rządów: „otrzymałem od hr. Thuna [austriacki prezydent ministrów] odpowiedź, że porozumiał się z węgierskim prezydentem Ministrów Bánffym, który wreszcie oświadczył, że [...] przeciw wyborowi [...] nie podniesie rząd węgierski żadnych zarzutów" "77, że dialog między arbitrami kierowany był przez rząd: ,że jednak na podstawie instrukcji od węgierskiego prezydenta Ministrów Szèlla"78. I wiele innych ${ }^{79}$.

\section{REALIZACJA USTAW OBU SEJMÓW}

W uzgodnionym przez oba rządy komplecie (Winkler, Tchorznicki, Lehoczky) sąd polubowny na posiedzeniu 5 i 6 kwietnia 1902 r. w Wiedniu, na podstawie opracowanego przez galicyjskiego arbitra projektu, przyjął swój statut ${ }^{80}$. Rozstrzy-

${ }^{71}$ „Die Feststellung des modus procedendi in Absicht auf die Schöpfung des Schiedsrichtersspruches bleibt selbsverständlich dem Ermessen des Schiedsgerichtes bezüglich der zu treffenden Vereinbarung dem Herrn Schiedsrichter anheimgegeben".

72 A. Mniszek-Tchorznicki, Wspomnienia moje..., s. 155.

73 Ibidem, s. 157.

${ }^{74}$ Ibidem, s. 170

75 Ibidem.

${ }^{76}$ Ibidem, s. 171.

77 Ibidem, s. 162.

78 Ibidem, s. 165.

79 Warto zauważyć, jak mocno Mniszek-Tchorznicki, sędzia trybunału arbitrażowego, został obciążony wykonywaniem zadań biurowo-administracyjnych, np. „starania o lokal odpowiedni w Grazu, o stenografów etc. pozostawiono mnie" (ibidem, s. 174) czy po wydaniu wyroku: ,ja zaś zapakowałem akta i popłaciwszy rachunki podążyłem także za nim [...] Lehoczkyemu musiałem przesłać wyrok przez specjalnego kuriera do Preszburga" (ibidem, s. 198).

${ }^{80}$ Ibidem, s. 170-171. Przekład polski statutu opublikowano w „Dzienniku Poznańskim” nr 198 z 28.08.1902 r., a powołuje go już Zofia Nowak. Wcześniej, bo z datą 26.08.1902 r. (nr 195, wyd. wieczorne) polski tekst opublikował krakowski „Czas”. Nie udało się jednak dotrzeć do oryginału statutu. Można jednak jego niemieckojęzyczny tekst (choć niepełny) znaleźć w opracowaniu 
gnięto w nim o składzie trybunału (choć uczyniono to już po obsadzeniu stanowisk), ostatecznie przyjmując, że sąd stanowi trzyosobowe kolegium ${ }^{81}$. Do pomocy arbitrom przydzielono każdej ze stron po jednym referencie $(\S 2 \text { statutu })^{82}$. Ponadto w rozprawie na posiedzeniach jawnych z prawem głosu mieli uczestniczyć niebędący członkami trybunału, a powoływani po jednym przez każdą stronę obrońcy interesów pozostających w sporze państw $(\S 6 \text { statutu })^{83}$. Statut określił zadania i funkcje poszczególnych osób, wskazał sposób podejmowania decyzji, przyjmując język niemiecki jako język postępowania ${ }^{84}$. Uregulował też zasady postępowania, stanowiąc, że każdy z rządów powinien zgromadzić całą dokumentację, jaką dysponuje w sprawie Morskiego Oka, i materiały te dostarczyć swojemu arbitrowi. Następnie obaj sędziowie rozjemczy „mają wyłuszczyć: stan rzeczy ściśle podług treści zakomunikowanych im przez rząd aktów, pretensye obu państw, przytoczone dowody i w końcu wynikające z tego punkty sporne - bez wypowiadania swego osobistego zapatrywania" ( $\$ 8$ statutu). Zatem i Lehoczky, i Tchorznicki winni występować przed trybunałem w sposób bezstronny, unikając komentarzy i oceny ${ }^{85}$. Arbitrzy nie zostali bowiem reprezentantami stron, które ich powołały. Mieli być obiektywnymi sędziami. Rolę adwokatów spierających się krajów przewidziano dla obrońców, wyznaczając czas na ich wystąpienia po zakończeniu przedstawienia przez arbitrów stanu sprawy ( $\S 6$ i 9 statutu).

Proces ustalania składu funkcjonariuszy, którzy mieli uczestniczyć w postępowaniu polubownym, przebiegał w chaotyczny sposób. Zanim bowiem doszło

W. Korna, Der Streit um das Meerauge zwischen Österreich und Ungarn, „Österreichich-Ungariche Revue, Monatschrift" 1907, t. 35, s. 12-13.

${ }^{81} \mathrm{~W}$ wyroku sądu polubownego wymieniono imiennie wszystkich siedmiu uczestników postępowania.

${ }^{82}$ Zostali nimi Wiktor Korn, powołany przez rząd austriacki i Ludwik Laban, powołany przez rząd węgierski. Referenci, jako pomocnicy arbitrów, nie wchodząc w skład sądu, mieli prawo uczestniczyć w obradach zamkniętych.

83 Oswald Balzer najpierw powołany został „w sprawie sporu granicznego przy Morskiem Oku" 18 marca 1898 r. na stanowisko delegata Wydziału Krajowego, w którego imieniu nominację podpisali Stanisław Badeni, ówcześnie marszałek Sejmu Krajowego, i Damian Sawczak, członek Wydziału Krajowego. Zob. A. Mniszek-Tchorznicki, Wspomnienia moje..., s. 161. Na przewidzianego w statucie sądu polubownego obrońcę interesów Austrii, na wniosek austriackiego arbitra, powołał prof. Balzera w kwietniu 1902 r. premier Kőrber. Po zakończeniu procesu Tchorznicki negatywnie ocenia zgłoszoną przez siebie personalną propozycję: „Niestety wybór ten, jak się później, przy rozprawie w Grazu okazało, był chybiony, zawiodłem się na prof. Balcerze bardzo" (ibidem). Weryfikacja roli prof. Balzera w procesie o Morskie Oko zostanie przedstawiona w odrębnym studium.

${ }^{84}$ Przedstawiane przed sądem materiały polsko- i węgierskojęzyczne miały być thumaczone przed sądem przez arbitrów. Założono, że łacinę i niemiecki członkowie sądu znają.

${ }^{85}$ Polscy obserwatorzy zarzucali Tchorznickiemu nadmierny obiektywizm i niedostrzeganie interesu Austrii; jednocześnie mieli pretensje do Lehoczkyego o nazbyt subiektywne eksponowanie prowęgierskiego materiału. 
do przyjęcia statutu trybunału arbitrażowego, w którym określono skład sądu i wskazano uczestników postępowania, to już wcześniej obsadzone zostały (jeszcze przed ich ustanowieniem) poszczególne stanowiska ${ }^{86}$. Innymi słowy, to nie statut określił organizację sądu polubownego, ale decyzje rządowe, które następnie, dopiero w kwietniu 1902 r., arbitrzy zapisali w statucie. Była to więc nieudana próba całkowitego uzależnienia sądu od rządowej biurokracji. W lipcu $1897 \mathrm{r}$. rząd węgierski wyraził wolę ustanowienia ,sekretarza węgierskiego ministerstwa jako swego rzeczoznawcę"87, sugerując, że za takiego uważa powołanego przez galicyjski Wydział Krajowy delegata, którym został Oswald Balzer. Wobec protestu polskiego arbitra intryga rządowa $\mathrm{w}$ tym zakresie się nie powiodła ${ }^{88}$. Trudno nie zgodzić się ze stanowiskiem Tchorznickiego. Inny charakter ma bowiem dla sądu subiektywnie działający obrońca strony, a inny - przygotowujący profesjonalną (obiektywną) ekspertyzę rzeczoznawca. Narzucenie biegłych przez rządy stanowiłoby ewenement proceduralno-organizacyjny, a zarazem istotnie ograniczałoby swobodę orzeczniczą trybunału.

\section{PODSUMOWANIE}

Przedstawiając proces tworzenia instytucji w celu rozstrzygnięcia austriacko-węgierskiego sporu granicznego, zwrócono uwagę na elementy, które świadczyły o oddziaływaniu rządu na decyzje powołanego organu. Można wśród nich wyróżnić:

- skłonność do zachowania zależności od rządu organu, który miał zostać powołany do rozstrzygnięcia sporu granicznego. Widać ją we wszystkich informacjach wskazujących na pierwszym i na początku drugiego etapu, że organ ten miał mieć charakter komisji mieszanej, a więc podległej rządowi struktury administracyjnej i składać się z urzędników zależnych od rządu. Ponadto za taką wskazówkę należy uznać zastrzeżenia, przewidujące konieczność zatwierdzenia decyzji komisji przez organy władzy wykonawczej: rząd i cesarza;

- daleko posuniętą zależność organizacyjną sędziów polubownych, uzgadniających (niemal) każdą decyzję z rządami, którą można zaobserwować w zapiskach polskiego arbitra;

${ }^{86}$ Kolejne daty nominacji: w 1897 r. arbitrzy - węgierski (przed 10 lipca) i austriacki (10 lipca); Wiktor Korn - jako referent - marzec 1898 r. O. Balzer nominowany był dwukrotnie na dwa stanowiska: najpierw powołano go na delegata Wydziału Krajowego (18 marca 1898 r.), a następnie (w kwietniu 1902 r.) został obrońcą interesów Austrii.

${ }^{87}$ A. Mniszek-Tchorznicki, Wspomnienia moje..., s. 157.

${ }^{88}$ „Ustanowienie zastępców obu rządów jako obrońców interesów Galicji i Węgier byłoby pożądane [...] na przyznanie tym zastępcom charakteru rzeczoznawców zgodzić się nie mogę" - pisał Mniszek-Tchorznicki (ibidem, s. 157). 
- podróż superarbitra, dr. Jana Winklera, przed wydaniem wyroku do Wiednia, na audiencję u cesarza Austrii, a zarazem króla Węgier oraz na spotkanie tego samego dnia z premierem Węgier;

- honory czynione przez władze członkom trybunału i nagrody przyznawane jeszcze przed wydaniem wyroku przez sąd rozjemczy ${ }^{89}$;

- budzące wątpliwości prowadzenie postępowania, charakter argumentacji i podstawa wydanego orzeczenia: brak zaangażowania w przygotowanie obrony swojego stanowiska przez Węgrów, oddanie w ręce naukowca, który nigdy nie brał udziału w praktyce sądowej i nie rozumiał, czym różni się wywód naukowy od przeprowadzenia dowodu przed sądem, obrony interesów Galicji przed trybunałem w $\mathrm{Grazu}^{90}$, brak powołania się na mocne, łatwo dostępne jeszcze dziś dowody przez obie strony;

- dowód w postaci wizji lokalnej, która zapewniała niemal całkowitą swobodę organu wydającego wyrok. Mimo pozorów obiektywizmu daje ona największą możliwość subiektywnego kształtowania decyzji na podstawie swobodnej oceny funkcjonariuszy w czynności uczestniczących. Nie dziwi zatem, że w toku całego opisanego procesu przy każdej nadarzającej się okazji zastrzegano prawo, czy nawet obowiązek, przeprowadzenia wizji lokalnej ${ }^{91}$.

\title{
THE ARBITRAL TRIBUNAL IN GRAZ - \\ SHAPING OF THE ORGANIZATIONAL CONCEPT OF RESOLVING A BORDER DISPUTE AND THE SUBTEXT OF THIS TRIAL
}

\begin{abstract}
The dispute over the Austro-Hungarian border at Morskie Oko was, after the predatory partition of Poland in 1772, a continuation of a border conflict between the Kingdom of Poland and Hungary which started in the $16^{\text {th }}$ century. The attempts to amicably delineate the border did not yield any results for the majority of the $19^{\text {th }}$ century. In 1879 , Christian Hohenlohe, a Prussian Prince, bought a border estate situated on the Hungarian side (a village called Jaworzyna) and he subsequently took steps with a view to seize the disputed territory. However, Count Władysław Zamoyski purchased lands in Galicia (Zakopane), located on the other side of the border, in 1889 and then he firmly resisted the claims of the Prussian magnate. The conflict concerning private property (a civil law conflict) continued to escalate and resulted in violence in the area and ended up in courts afterwards. However, without determining the political (state) affiliation of the disputed territory, no decisions made by the courts could be binding for the feuding parties. In the face of danger to safety and peace at the Austro-Hungarian border (there were even threats aimed at

${ }^{89}$ Szerzej: J. Matuszewski, Przypadek sądu polubownego z 1902 roku, Warszawa 2021.

90 Ibidem.

${ }^{91}$ Zagadnienie wizji lokalnej (,naoczni”), która miała miejsce w postępowaniu o granicę przy Morskim Oku, zostanie przedstawione w odrębnym artykule.
\end{abstract}


Galician court clerks with the use of firearms by Hungarian gendarmes), the governments in Vienna and Budapest came to a covert agreement and delineated a demarcation line. It was deemed that public disclosure of the compromise as well as of the concessions made by both parties would be used in political conflicts in both countries. As a consequence, it was decided that the blame should be put on the international arbitral tribunal. The paper presents solutions as well as the legal and political instruments used by both governments in order to secure such a court decision which would implement the international agreement they had previously reached and, at the same time, it would allow to lay the blame for the concessions on the tribunal.

Keywords: Franz Joseph I as a mediator, political relations in government of Austro-Hungarian monarchy, international arbitral tribunal in Graz of 1902, dispute over Morskie Oko, Count Władysław Zamoyski 